\title{
Anti-phospholipase A2 receptor antibody in membranous nephropathy; an Indian experience
}

\author{
Monika Yachha, Raj Kumar Sharma*, Sonia Mehrotra, Narayan Prasad, Amit Gupta, Anupma Kaul, \\ Dharmendra Singh Bhadauria
}

Department of Nephrology, Sanjay Gandhi Post Graduate Institute of Medical Sciences, Lucknow, India

\section{A R T I C L E I N F O}

Article Type:

Original

\section{Article History:}

Received: 4 April 2017

Accepted: 8 Auguat 2017

Published online: 30 Auguat 2017

\section{Keywords:}

Membranous nephropathy

Anti-PLA2R autoantibodies

Immunosuppressive therapy

\begin{abstract}
A B S T R A C T
Introduction: Autoantibodies against phospholipase-A2 Receptor ( $\mathrm{PLA}_{2} \mathrm{R}$ ), a normally occurring antigen presented on podocyte membranes, have recently been implicated in the pathology of membranous nephropathy $(\mathrm{MN})$.

Objectives: In this observational study, we have evaluated the correlation of patient's disease activity against serum levels of anti-PLA ${ }_{2} \mathrm{R}$ in patients with primary and secondary $\mathrm{MN}$ in a North Indian cohort.

Patients and Methods: We measured serum anti-PLA $\mathrm{R}_{2}$ antibody by ELISA in 63 adult patients with MN. Out of these 63 patients, the majority (58) had primary MN (pMN) and the remaining five had secondary $\mathrm{MN}$ (sMN).

Results: Around $55.2 \%$ had detectable anti-PLA $\mathrm{R}_{2}$ autoantibodies $(63 \%$ in those with newonset pMN, $67 \%$ in patients with relapse and $3 \%$ in patients in remission). However, all patients with refractory $\mathrm{pMN}(\mathrm{n}=4)$ were anti-PLA $\mathrm{R}_{2}$ negative. There was significantly higher anti-PLA $\mathrm{R}_{2}$ positivity in active stage of disease in contrast to those in remission $(P<0.001)$. Autoantibody level was proportional to the disease activity, with a trend towards significance $(P=0.052)$. Hypoalbuminemia and proteinuria were also significantly worse in the anti$\mathrm{PLA}_{2} \mathrm{R}$ positive patients. All patients with sMN tested negative for anti-PLA ${ }_{2} \mathrm{R}$ autoantibodies. Conclusion: $\mathrm{PLA}_{2} \mathrm{R}$ is a major target antigen in Indian population with idiopathic MN. Anti$\mathrm{PLA}_{2} \mathrm{R}$ positivity is a specific tool to detect idiopathic MN, and its levels correspond well with other disease activity markers. In addition, anti-PLA $\mathrm{R}_{2}$ antibody was negative in refractory pMN, which suggests the existence of additional autoantibodies in this subgroup, with a different target antigen. These autoantibodies may be resistant to the currently recommended immunosuppressants for the disease, thus the refractory nature of the disease.
\end{abstract}

Implication for health policy/practice/research/medical education:

In an observational study, aroup of patients with membranous nephropathy showed correlation of anti-PLA2R antibodies with disease activity and presence of primary MN.

Please cite this paper as: Yachha M, Sharma RK, Mehrotra S, Prasad N, Gupta A, Kaul A, Bhadauria DS. Anti-phospholipase A2 receptor antibody in membranous nephropathy; an Indian experience. J Renal Inj Prev. 2018;7(1):16-21. DOI: 10.15171/jrip.2018.04.

\section{Introduction}

Membranous nephropathy ( $\mathrm{MN})$ is amongst the most common aetiologies of nephrotic syndrome in adults, particularly in the non-diabetic population (1-3). In majority, almost three-quarter cases, $\mathrm{MN}$ is idiopathic or primary (pMN), however in remaining patients, it occurs secondary to a variety of conditions including hepatitis B, systemic lupus erythematosus (SLE), thyroiditis, malignancies and drugs like gold, penicillamine and captopril $(4,5)$. Based on the rat model of Heymann's nephritis, autoimmune mechanisms were implicated in the genesis of MN (6,7). In 2009, Beck et al in their landmark study reported $M$-type phospholipase $A_{2}$ receptor $\left(\mathrm{PLA}_{2} \mathrm{R}\right)$, on glomerular podocytes, to be the target antigen in 26 of their $37(70 \%)$ patients having idiopathic $\mathrm{MN}$ (iMN). The circulating anti-PLA $\mathrm{R}$ antibodies target a specific region of the $\mathrm{PLA}_{2} \mathrm{R}$ protein and are predominantly of the IgG4-type (8-11). Similar 
results with prevalence of anti-PLA 2 R antibodies ranging from $60 \%-80 \%$ in idiopathic $\mathrm{MN}$ have been observed by different researchers worldwide (12-17). The anti-PLA $\mathrm{R}_{2}$ antibodies have been associated with high specificity and sensitivity of approximately $95 \%$ and $75 \%$ respectively for diagnosis of pMN. Few recent studies have also reported correlation of anti-PLA 2 R levels with the clinical severity, with higher spontaneous remission rates observed in patients and with lower antibody titres. They can therefore be considered as a non-invasive marker for both diagnosis and prognosis in iMN (14-19). The US Food and Drug Administration (FDA) in 2014, accepted two commercially available tests for anti-PLA 2 R autoantibodies, including an enzyme-linked immunosorbent assay (ELISA) and indirect immunofluorescence assay (IIFA).

\section{Objectives}

In this observational study from a tertiary institute in North India, we have evaluated the correlation of patient's disease activity with serum anti-PLA $\mathrm{R}_{2}$ levels in primary and secondary forms of $\mathrm{MN}$ with variable levels of disease activity.

\section{Patients and Methods \\ Patients}

Adult patients $\geq 18$ years of age, with biopsy-proven $\mathrm{MN}$, including newly diagnosed secondary $\mathrm{MN}$ were prospectively enrolled over a period of 12 months, from January 2015 to December 2015.

Majority of the patients were started on angiotensinconverting-enzyme inhibitor (ACE inhibitor) or angiotensin II receptor blockers (ARBs). Decision to initiate immunosuppressive therapy (IST) was made in the follow-up, depending on the trending levels of 24hour urinary-protein and serum creatinine (according to KDIGO guidelines 2012). Baseline characteristics of all the patients were recorded at the beginning of the study. All patients were worked up for any underlying secondary cause of $\mathrm{MN}$, which included assessment of viral markers, ANA, anti-dsDNA, C3, C4, chest X-ray, PSA in men, breast examination in women, stool for occult blood, history of any implicated drugs. Patients were accordingly labelled as having pMN or sMN. 'New-onset disease' was defined as patients with having $<6$ months of diagnosis and no previous exposure to immunosuppressive therapy. Remission, relapse and refractory disease were defined according to the KDIGO 2012 definitions (20). Clinical data was prospectively collected.

\section{Quantification of circulating anti-PLA $A_{2} R$}

ELISA kit (EUROIMMUN AG, Lubick, Germany) containing $\mathrm{PLA}_{2} \mathrm{R} 1$-coated microplates was used to determine the circulating anti-PLA $\mathrm{R}$ antibody levels. After incubation with human sera, diluted 1:100 in sample for 30 minutes, antibodies were detected with anti-human IgG horse-radish peroxidase conjugate (EUROIMMUN AG) diluted 1:1000 in sample buffer for 30 minutes. Chromogen substrate solution (EUROIMMUN AG) was added for 15 minutes after washing. Stopping solution was thereafter used to stop the reaction. An automated microplate, absorbance reader (iMark, Bio-Rad, Veenendaal, the Netherlands) was used to read optical density. $\mathrm{PLA}_{2} \mathrm{R}$ levels of $>20 \mathrm{RU} / \mathrm{mL}$ were considered to be positive, $<14$ were taken as negative and levels between 14 and $20 \mathrm{RU} / \mathrm{mL}$ were taken as borderline as per the manufacturer specifications.

\section{Ethical consideration}

The study has been approved by the Institute Ethical Committee of Sanjay Gandhi Post Graduate Institute of Medical Sciences. Written informed consent was obtained from all patients. All participating patients gave written informed consent prior to inclusion in the study.

\section{Statistical analysis}

Continuous variables were presented as the mean \pm SD. Frequencies or percentages were used to describe categorical variables. Differences in continuous and categorical variables were assessed using the independent sample $t$ test/Mann-Whitney $U$ test and chi-square / Fisher's exact test, respectively. SPSS version 20 for Windows (IBM, Chicago, Ill., USA) was used for statistical analysis.

Results

Primary versus secondary $M N$

Amongst 63 patients with $\mathrm{MN}$ in our study, 58 patients (92\%) had pMN, while 5 patients (8\%) had sMN. Amongst patients with sMN, 4 patients had SLE and 1 had hepatitis B infection. Majority of patients with pMN were males $(\mathrm{M}: \mathrm{F}=2.4)$, whereas all the patients with $\mathrm{sMN}$ were females (SLE being the predominant cause). Mean age of patients with iMN and sMN were 39 years and 32 years respectively. Nearly $57 \%$ of patients of iMN $(n=33)$ had already been initiated on immunosuppressive therapy (IST) at the time of inclusion in the study (modified Ponticelli regimen or calcineurin inhibitors or both), whereas only 1 patient (20\%) with sMN had already been put on IST for lupus nephritis. All patients with sMN tested negative for anti-PLA 2 R despite having slightly more severe disease, with higher degree of proteinuria (3656 mg/day versus $3484 \mathrm{mg} /$ day, respectively) and more severe hypoalbuminemia $(2.52 \mathrm{~g} / \mathrm{dL}$ versus $3.37 \mathrm{~g} / \mathrm{dL}$ in sMN and pMN respectively (Table 1 ).

\section{Patient characteristics in primary membranous nephropathy}

Half $(n=29(50 \%))$ of the patients with pMN had active disease at the start of study. One-third of our study population were newly diagnosed and had not received any treatment. Six patients (10\%) were with disease relapse and $4(7 \%)$ with refractory disease. The remaining $29(50 \%)$ had responded to treatment and were under remission.

Amongst the newly diagnosed cases of pMN, 12 cases $(63 \%)$ were anti-PLA R positive. Similarly, 4 (67\%) with 
Table 1. Primary versus secondary membranous nephropathy

\begin{tabular}{lcc}
\hline & pMN & sMN \\
\hline Subject, No. (\%) & $58(92)$ & $5(8)$ \\
Male, No. (\%) & $41(71)$ & $0(0)$ \\
Age (y) (mean \pm SD) & $38.9 \pm 12.7(18-63)$ & $31.8 \pm 12.6(18-50)$ \\
IST, No. (\%) & $33(57)$ & $1(20)$ \\
24-Hour urinary protein (mg) (mean \pm SD) & $3484 \pm 3968$ & $3656 \pm 2330$ \\
Serum albumin (g/dL) (mean \pm SD) & $3.37 \pm 0.88$ & $2.52 \pm 1.43$ \\
Serum creatinine (mg/dL) (mean \pm SD) & $1.37 \pm 1.14$ & $1.04 \pm 0.43$ \\
PLA 2 R positivity (\%) & $55.2 \%$ (with active disease) \\
\hline
\end{tabular}

Abbreviations: pMN, Primary membranous nephropathy; sMN, Secondary membranous nephropathy; IST, immunosuppressive therapy.

relapse had positive values of $\mathrm{PLA}_{2} \mathrm{R}$ antibodies (Table 2). However, none of the patients who were refractory to treatment had $\mathrm{PLA}_{2} \mathrm{R}$ reactivity (Tables 3 and 4 ). Only $4 \%$ of those in remission were $\mathrm{PLA}_{2} \mathrm{R}$ positive (Table 2).

For further analysis, we grouped the pMN patients with active disease together (those with persistent nephrotic proteinuria, relapse of disease after achieving remission and refractory disease) and compared them to the cohort in remission. The anti- $\mathrm{PLA}_{2} \mathrm{R}$ was significantly more positive in the active pMN group (55.2\% in pMN versus $3 \%$ in sMN) $(P<0.001)$ and the anti- PLA $\mathrm{R}$ levels also had a trend towards significance $(103 \pm 275 \mathrm{RU} / \mathrm{mL}$ in pMN versus $2 \pm 5 \mathrm{RU} / \mathrm{ml}$ in $\mathrm{sMN})(P=0.05)$.

Correlation of clinical activity in pMN patients with anti-PLA2R levels

The anti-PLA 2 R levels correlated with the disease activity.
Those with anti-PLA 2 R positivity, had significantly lower levels of serum albumin and higher levels of proteinuria $(P<0.01)$ (Figure 1). However there was no significant difference in serum creatinine and cholesterol levels among the groups. Anti-PLA 2 R positivity was also directly proportional to age, with the mean being 45 years in the $\mathrm{PLA}_{2} \mathrm{R}$ positive group as compared to 36 years in the other group $(P=0.01$; Table 5$)$.

\section{Discussion}

This study was designed to validate $\mathrm{PLA}_{2} \mathrm{R}$ antibody trends in North Indian patients with MN. Amongst the $\mathrm{iMN}$ patients, we found anti-PLA $\mathrm{R}$ positivity in $55.2 \%$ of patients with active disease, in $63 \%$ of the newly diagnosed untreated patients, and in $67 \%$ with full-blown relapse of disease. This prevalence of anti$\mathrm{PLA}_{2} \mathrm{R}$ is in concordance with other studies which have

Table 2. Baseline characteristics of patients with primary membranous nephropathy

\begin{tabular}{|c|c|c|c|c|}
\hline \multirow{2}{*}{ Patient characteristics } & \multicolumn{4}{|c|}{ Subtypes of pMN } \\
\hline & New (Treatment-naïve) & Relapse & Refractory & Remission \\
\hline Subject, No. (\%) & $19(33)$ & $6(10)$ & $4(7)$ & $29(50)$ \\
\hline Male, No. (\%) & $17(90)$ & $5(83)$ & $3(75)$ & $16(55)$ \\
\hline Age $(y)$ (mean $\pm S D)$ & $41 \pm 14(18-63)$ & $41 \pm 14(18-56)$ & $29 \pm 15(18-50)$ & $39 \pm 11(18-58)$ \\
\hline 24-Hour urinary protein $(\mathrm{mg})($ mean $\pm \mathrm{SD})$ & $6991 \pm 4531$ & $5175 \pm 2954$ & $3910 \pm 1094$ & $778 \pm 778$ \\
\hline Serum creatinine $(\mathrm{mg} / \mathrm{dl})($ mean $\pm \mathrm{SD})$ & $1.33 \pm 0.61$ & $0.95 \pm 0.29$ & $1.84 \pm 1.5$ & $1.42 \pm 1.44$ \\
\hline Serum albumin $(\mathrm{g} / \mathrm{dL})($ mean $\pm \mathrm{SD})$ & $2.69 \pm 0.94$ & $3.47 \pm 0.69$ & $3.02 \pm 0.7$ & $3.84 \pm 0.54$ \\
\hline $\mathrm{PLA}_{2} \mathrm{R}$ positive, No. (\%) & $12(63)$ & $4(67)$ & $0(0)$ & $1(3)$ \\
\hline Anti-PLA ${ }_{2} R(R U / m L)($ mean $\pm S D)$ & $143 \pm 335$ & $41 \pm 37$ & $6 \pm 6$ & $2 \pm 5$ \\
\hline
\end{tabular}

Abbreviations: pMN, primary membranous nephropathy.

Table 3. Comparison of pMN patients as per disease activity

\begin{tabular}{|c|c|c|c|}
\hline \multirow{2}{*}{ Patient characteristics } & \multicolumn{3}{|c|}{ Subtypes of pMN } \\
\hline & With active disease (new + relapse + refractory) & With remission & $P$ value \\
\hline Subject, No. (\%) & $29(50)$ & $29(50)$ & \\
\hline Male, No. (\%) & $25(86)$ & $16(55)$ & 0.09 \\
\hline Age $(y)($ mean \pm SD) & $39 \pm 14(18-63)$ & $39 \pm 11(18-58)$ & 086 \\
\hline 24-Hour urinary protein $(\mathrm{mg})$ (mean \pm SD) & $6190 \pm 4035$ & $778 \pm 778$ & $<0.001$ \\
\hline Serum creatinine $(\mathrm{mg} / \mathrm{dL})($ mean $\pm \mathrm{SD})$ & $1.32 \pm 0.75$ & $1.42 \pm 1.44$ & 0.756 \\
\hline Serum albumin $(\mathrm{g} / \mathrm{dL})$ (mean $\pm \mathrm{SD})$ & $2.90 \pm 0.90$ & $3.84 \pm 0.54$ & $<0.001$ \\
\hline PLA 2 R positive, No. $(\%)$ & $16(55.2)$ & $1(3)$ & $<0.001$ \\
\hline Anti-PLA ${ }_{2} R(R U / m L)($ mean $\pm S D)$ & $103 \pm 275$ & $2 \pm 5$ & 0.05 \\
\hline
\end{tabular}

Abbreviations: $\mathrm{PMN}$, primary membranous nephropathy. 
Table 4. Characteristics of primary membranous nephropathy patients with refractory disease

\begin{tabular}{|c|c|c|c|c|c|c|}
\hline Age (y)/gender & $\begin{array}{l}\text { Disease duration } \\
\text { (y) }\end{array}$ & $\begin{array}{l}\text { Proteinuria } \\
(\mathrm{mg} / \mathrm{d})\end{array}$ & $\begin{array}{l}\text { Serum Albumin } \\
(\mathrm{g} / \mathrm{dL})\end{array}$ & $\begin{array}{l}\text { Serum creatinine } \\
(\mathrm{mg} / \mathrm{dL})\end{array}$ & $\begin{array}{c}\text { Anti- PLA } 2 \text { (RU/ } \\
\mathrm{mL})\end{array}$ & IST received \\
\hline $21 / M$ & 3 & 5400 & 3.0 & 1.10 & 6.06 & $\mathrm{P}+\mathrm{CNI}+\mathrm{MMF}$ \\
\hline $50 / \mathrm{M}$ & 8 & 2800 & 3.7 & 4.10 & 14.5 & $\mathrm{P}+\mathrm{CNI}$ \\
\hline $26 / F$ & 4 & 3540 & 2.0 & 1.08 & 0.00 & $\mathrm{P}+\mathrm{CNI}+\mathrm{Ritu}$ \\
\hline $18 / \mathrm{M}$ & 4 & 3900 & 3.4 & 1.10 & 3.96 & $\mathrm{P}+\mathrm{CNI}$ \\
\hline
\end{tabular}

Abbreviations: IST, immunosuppressive therapy; P, modified ponticelli regimen; CNI, calcineurin Inhibitor, MMF, mycofenolate mofetil; Ritu, rituximab.

Table 5. Clinical characteristics of patients with idiopathic membranous nephropathy according to anti-PLA ${ }_{2} R$ reactivity

\begin{tabular}{|c|c|c|c|}
\hline Anti-PLA 2 R antibody & Negative $(n=41)$ & Positive ( $n=17$ ) & $P$ value \\
\hline Male, No. (\%) & $28(68)$ & $13(76)$ & 0.53 \\
\hline Age at diagnosis (y) & 36 & 45 & 0.01 \\
\hline 24-Hour Urinary protein (mg/d) & $2181 \pm 3520$ & $6466 \pm 3394$ & $<0.001$ \\
\hline Urinary protein $\geq 3.5$ g/d, No. (\%) & $7(17 \%)$ & $15(88 \%)$ & $<0.001$ \\
\hline Serum albumin (g/dL) & $3.67 \pm 0.64$ & $2.66 \pm 0.97$ & $<0.001$ \\
\hline Serum albumin (<3.5 g/dL), No. (\%) & $14(34)$ & $14(82)$ & $<0.001$ \\
\hline Serum creatinine $(\mathrm{mg} / \mathrm{dL})$, mean $\pm S D$ & $1.47 \pm 1.38$ & $1.19 \pm 0.47$ & 0.42 \\
\hline Serum cholesterol (mg/dL), mean \pm SD & $217.66 \pm 87.7$ & $271.8 \pm 136.6$ & 0.08 \\
\hline
\end{tabular}

reported seropositivity ranging from 52\%-82\% (19-23). In another study of 114 newly diagnosed pMN patients from India, Ramachandran et al found, $66.7 \%$ antiPLA $_{2} \mathrm{R}$ positivity (by ELISA) (24). Lower prevalence in our study may be explained by the fact that we included patients with relapse and refractory disease in our study group. The anti-PLA ${ }_{2} \mathrm{R}$ negativity in these patients can be explained by the possible presence of other target antigens implicated in pathogenesis of idiopathic MN such as non$\mathrm{PLA}_{2} \mathrm{R}$ podocyte antigens (25). Anti-PLA $\mathrm{R}_{2}$ was negative in five patients with secondary MN, majority with SLE as the secondary cause. This is consistent with the current data of anti-PLA ${ }_{2} \mathrm{R}$ antibody's specificity for idiopathic MN (8,12-17,26).

Amongst subjects in clinical remission, $\mathrm{PLA}_{2} \mathrm{R}$ was detectable in just one of 29 patients (3\%). In contrast, 4 of 6 patients (67\%) with relapse had positive PLA 2 R antibodies, thus further corroborating the fact that the levels of $\mathrm{PLA}_{2} \mathrm{R}$ reflect disease activity. Previous studies have also

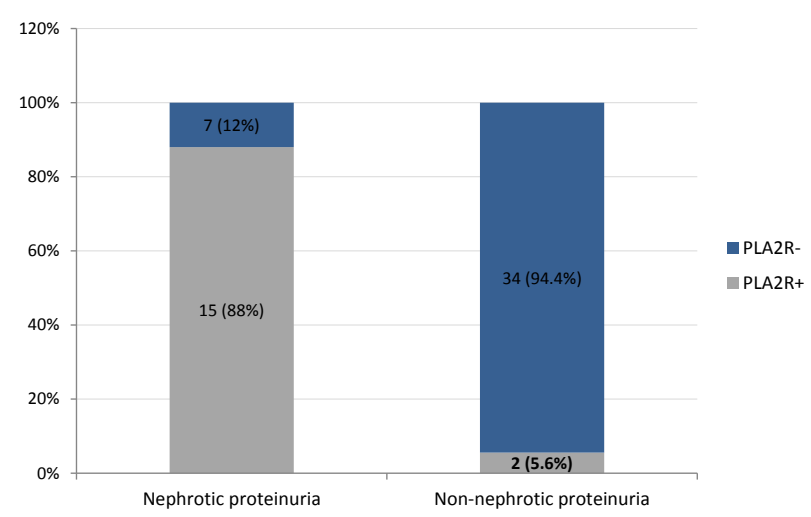

Figure 1. Prevalence of nephrotic-proteinuria in idiopathic membranous nephropathy according to PLA2R activity. shown that, the antibody titres disappear with remission and reappear with disease relapses $(8,13,14,17,18,27-32)$. Moreover, anti-PLA ${ }_{2} \mathrm{R}$ levels were in direct proportion to proteinuria and serum albumin levels.

Absence of the PLA ${ }_{2} \mathrm{R}$ antibodies in the four treatmentrefractory patients is suggestive of presence of antibodies to some unidentified antigens, leading to a more resistant variant of the disease. Thus, the aforementioned subgroup requires further genetic and autoimmune evaluation to look for these yet unidentified autoantibodies.

No significant difference was observed in the serum creatinine levels between $\mathrm{PLA}_{2} \mathrm{R}$-positive patients and those with undetectable levels of these antibodies. Males were affected more than females $(\mathrm{M}: \mathrm{F}=2.4)$. Majority of our patients were in their third or fourth decade of life. These findings are in consistent with those reported in the literature (33).

\section{Conclusion}

To conclude, our data adds weight to the fact that anti$\mathrm{PLA}_{2} \mathrm{R}$ is a relatively sensitive and specific marker of idiopathic $\mathrm{MN}$ in Indian population. Furthermore anti$\mathrm{PLA}_{2} \mathrm{R}$ positivity and levels correlate with disease activity, with more severe proteinuria and lower serum albumin levels in antibody positive patients. Absence of anti$\mathrm{PLA}_{2} \mathrm{R}$ in patients with refractory pMN needs further validation and could be suggestive of more severe form of disease with different immune mechanism. Thus, anti$\mathrm{PLA}_{2} \mathrm{R}$ positivity by ELISA could possibly replace kidney biopsy in patients with suspected $\mathrm{MN}$, and therefore may help to diagnose and predict the disease activity.

Limitations of the study

Our study had certain limitations. We had a relatively small sample size. Our study was confined to patients 
from Northern Indian belt. In patients in remission, we did not have the baseline anti-PLA ${ }_{2}$ levels when they had proteinuria, and there was lack of follow-up levels of anti$\mathrm{PLA}_{2} \mathrm{R}$ antibody

\section{Acknowledgments}

This study was supported by grants from Intramural Research funds of Sanjay Gandhi Post Graduate Institute of Medical Sciences, Lucknow.

\section{Authors' contribution}

Design and concept; MY and RKS. Data analysis; MY. The writing of the manuscript; MY, RKS, SM, NP, AG, AK and DSB. Data collection; MY and SM. Critical revision and finalizing paper; RKS. All authors read and signed the final paper.

\section{Conflicts of interest}

The authors declare no conflict of interest.

\section{Ethical considerations}

Ethical issues (including plagiarism, data fabrication, double publication) have been completely observed by the authors.

\section{Funding/Support}

Intramural grants of Sanjay Gandhi Post Graduate Institute of Medical Sciences, Lucknow.

\section{References}

1. Haas M, Meehan SM, Karrison TG, Spargo BH. Changing etiologies of unexplained adult nephrotic syndrome: a comparison of renal biopsy findings from 1976-1979 and 1995-1997. Am J Kidney Dis. 1997;30:621-31.

2. Braden GL, Mulhern JG, O'Shea MH, Nash SV, Ucci AA Jr, Germain MJ. Changing incidence of glomerular diseases in adults. Am J Kidney Dis. 2000;35:878-83.

3. Korbet SM, Genchi RM, Borok RZ, Schwartz MM. The racial prevalence of glomerular lesions in nephrotic adults. Am J Kidney Dis. 1996;27:647-51.

4. Austin HA 3rd, Antonovych TT, MacKay K, Boumpas DT, Balow JE. NIH conference. Membranous nephropathy. Ann Intern Med. 1992;116(8):672-82.

5. Wasserstein AG. Membranous glomerulonephritis. J Am Soc Nephrol. 1997;8:664-74.

6. Quigg RJ. Why study membranous nephropathy in rats? Kidney Int. 2003;64:2318-9.

7. Farquhar MG, Saito A, Kerjaschki D, Orlando RA. The Heymann nephritis antigenic complex: megalin (gp330) and RAP. J Am Soc Nephrol. 1995;6:35-47.

8. Beck LH Jr, Bonegio RG, Lambeau G, Beck DM, Powell DW, Cummins TD, et al. M-type phospholipase A2 receptor as target antigen in idiopathic membranous nephropathy. $\mathrm{N}$ Engl J Med. 2009;361:11-21. doi:10.1056/NEJMoa0810457.

9. Fresquet M, Jowitt TA, Gummadova J, Collins R, O'Cualain $\mathrm{R}$, McKenzie EA, et al. Identification of a major epitope recognized by PLA2R autoantibodies in primary membranous nephropathy. J Am Soc Nephrol. 2015;26:302-13. doi: 10.1681/ASN.2014050502.

10. Kao L, Lam V, Waldman M, Glassock RJ, Zhu Q.
Identification of the immunodominant epitope region in phospholipase A2 receptor-mediating autoantibody binding in idiopathic membranous nephropathy. J Am Soc Nephrol. 2015;26291-301. doi: 10.1681/ASN.2013121315.

11. BeckLH Jr. The dominant humoral epitope in phospholipase A2 receptor-1: presentation matters when serving up a slice of $\pi$. J Am Soc Nephrol. 2015;26:237-9. doi: 10.1681/ ASN.2014090877.

12. Debiec H, Ronco P. PLA2R autoantibodies and PLA2R glomerular deposits in membranous nephropathy. N Engl J Med. 2011; 364:689-90. doi:10.1056/NEJMc1011678.

13. Qin W, Beck LH Jr, Zeng C, Chen Z, Li S, Zuo K, et al. Anti-phospholipase A2 receptor antibody in membranous nephropathy. J Am Soc Nephrol. 2011;22:1137-43. doi: 10.1681/ASN.2010090967.

14. Hofstra JM, Beck LH Jr, Beck DM, Wetzels JF, Salant DJ. Anti-phospholipase $\mathrm{A}_{2}$ receptor antibodies correlate with clinical status in idiopathic membranous nephropathy. Clin J Am Soc Nephrol. 2011;6:1286-91. doi: 10.2215/ CJN.07210810.

15. Hofstra JM, Debiec H, Short CD, Pellé T, Kleta R, Mathieson PW, et al. Antiphospholipase A2 receptor antibody titer and subclass in idiopathic membranous nephropathy. J Am Soc Nephrol. 2012; 23:1735-43. doi: 10.1681/ASN.2012030242

16. Kanigicherla D, Gummadova J, McKenzie EA, Roberts SA, Harris S, Nikam M, et al. Anti-PLA2R antibodies measured by ELISA predict long-term outcome in a prevalent population of patients with idiopathic membranous nephropathy. Kidney Int. 2013;83:940-8. doi: 10.1038/ ki.2012.486.

17. Ruggenenti P, Debiec H, Ruggiero B, Chianca A, Pellé T, Gaspari F, et al. Anti-phospholipase A2 receptor antibody titer predicts post-rituximab outcome of membranous nephropathy. J Am Soc Nephrol. 2015;26:2545-58. doi:10.1681/ASN.2014070640.

18. Beck LH Jr, Fervenza FC, Beck DM, Bonegio RG, Malik FA, Erickson SB, et al. Rituximab-induced depletion of antiPLA2R autoantibodies predicts response in membranous nephropathy. J Am Soc Nephrol. 2011;22:1543-50. doi: 10.1681/ASN.2010111125.

19. Svobodova B, Honsova E, Ronco P, Tesar V, Debiec H. Kidney biopsy is a sensitive tool for retrospective diagnosis of PLA2R-related membranous nephropathy. Nephrol Dial Transplant. 2013;28:1839-44. doi:10.1093/ndt/gfs439.

20. Kidney Disease. Improving Global Outcomes (KDIGO) Glomerulonephritis Work Group. KDIGO Clinical Practice Guideline for Glomerulonephritis. Kidney Int Suppl. 2012; 2:139-274.

21. Hofstra JM, Wetzels JF. Anti-PLA $A_{2} R$ antibodies in membranous nephropathy: ready for routine clinical practice? Neth J Med. 2012;70:109-13.

22. Ong L, Silvestrini R, Chapman J, Fulcher DA, Lin MW.Validation of a phospholipase A2 receptor antibody ELISA in an Australian cohort with membranous glomerulonephritis. Pathology. 2016;48:242-6. doi: 10.1016/j.pathol.2016.02.001.

23. Akiyama S, Akiyama M, Imai E, Ozaki T, Matsuo S, Maruyama S. Prevalence of anti-phospholipase A2 receptor antibodies in Japanese patients with membranous nephropathy. Clin Exp Nephrol. 2015;19:653-60. doi: 10.1007/s10157-014-1054-2.

24. Ramachandran R, Kumar V, Kumar A, Yadav AK, Nada $\mathrm{R}$, Kumar H, et al. PLA2R antibodies, glomerular PLA2R 
deposits and variations in PLA2R1 and HLA-DQA1 genes in primary membranous nephropathy in South Asians. Nephrol Dial Transplant. 2016;31:1486-93. doi:10.1093/ ndt/gfv399.

25. Murtas C, Bruschi M, Candiano G, Moroni G, Magistroni $\mathrm{R}$, Magnano A, et al. Coexistence of different circulating anti-podocyte antibodies in membranous nephropathy. Clin J Am Soc Nephrol. 2012;7:1394-400.

26. Hoxha E, Harendza S, Zahner G, Panzer U, Steinmetz $\mathrm{O}$, Fechner K, et al. An immunofluorescence test for phospholipase- $\mathrm{A}_{2}$-receptor antibodies and its clinical usefulness in patients with membranous glomerulonephritis. Nephrol Dial Transplant. 2011;26:2526-32. doi: 10.1093/ ndt/gfr247.

27. Lv J, Hou W, Zhou X, Liu G, Zhou F, Zhao N, et al. Interaction between PLA2R1 and HLA-DQA1 variants associates with anti-PLA2R antibodies and membranous nephropathy. J Am Soc Nephrol. 2013;24:1323-9.doi: 10.1681/ASN.2012080771.

28. Oh YJ, Yang SH, Kim DK, Kang SW, Kim YS. Autoantibodies against phospholipase A2 receptor in Korean patients with membranous nephropathy. PLoS One. 2013;8:e62151. doi: 10.1371/journal.pone.0062151.

29. Bech AP, Hofstra JM, Brenchley PE, Wetzels JF.
Association of anti-PLA ${ }_{2} \mathrm{R}$ antibodies with outcomes after immunosuppressive therapy in idiopathic membranous nephropathy. Clin J Am Soc Nephrol. 2014;9:1386-92. doi: 10.2215/CJN.10471013.

30. Hoxha E, Thiele I, Zahner G, Panzer U, Harendza S, Stahl RA. Phospholipase A2 receptor autoantibodies and clinical outcome in patients with primary membranous nephropathy. J Am Soc Nephrol. 2014;25:1357-66. doi:10.1681/ASN.2013040430.

31. Hoxha E, Harendza S, Pinnschmidt H, Panzer U, Stahl RA. M-type phospholipase A2 receptor autoantibodies and renal function in patients with primary membranous nephropathy. Clin J Am Soc Nephrol. 2014;9:1883-90. doi: 10.2215/CJN.03850414.

32. Hoxha E, Harendza S, Pinnschmidt H, Panzer U, Stahl RA. PLA2R antibody levels and clinical outcome in patients with membranous nephropathy and non-nephrotic range proteinuria under treatment with inhibitors of the reninangiotensin system. PLoS One. 2014;9:e110681. doi: 10.1371/journal.pone.0110681.

33. Ronco P, Debiec H. Pathophysiological advances in membranous nephropathy: time for a shift in patient's care. Lancet. 2015;385:1983-92. doi: 10.1016/S01406736(15)60731-0.

Copyright @ $\odot 2018$ The Author(s); Published by Nickan Research Institute. This is an open-access article distributed under the terms of the Creative Commons Attribution License (http://creativecommons.org/licenses/by/4.0), which permits unrestricted use, distribution, and reproduction in any medium, provided the original work is properly cited. 